\title{
Twenty years of electroconvulsive therapy in a psychiatric unit at a university general hospital
}

\author{
Vinte anos de eletroconvulsoterapia em enfermaria psiquiátrica \\ de hospital geral universitário
}

\begin{abstract}
Amilton dos Santos Jr., ${ }^{1}$ Maitê Cruvinel Oliveira, ${ }^{1}$ Tiago dos Santos Andrade, ${ }^{1}$ Rosana Ramos de Freitas, ${ }^{1}$ Cláudio Eduardo Muller Banzato, ${ }^{2}$ Renata Cruz Soares de Azevedo, ${ }^{2}$ Neury José Botega²
\end{abstract}

\begin{abstract}
Objective: To describe the sociodemographic and clinical profile of patients who underwent electroconvulsive therapy (ECT) at a university general hospital.

Method: In this retrospective study, records from all patients undergoing ECT between January 1988 and January 2008 at the psychiatric unit of the general hospital of Universidade Estadual de Campinas (UNICAMP) were reviewed. Telephone contact was made with patients/relatives to collect follow-up data.

Results: A total of 200 charts were reviewed. The majority of patients were women, with a mean age of 39 years, and history of psychiatric hospitalization. The main indications for ECT were depression and catatonia. Complications were observed in less than half of the cases, and most were temporary and not severe. There was a good psychiatric outcome for $89.7 \%$ of the patients, especially for catatonic patients $(100 \%, p=0.02)$. Thirtyfour percent of the cases were later contacted by telephone calls, at a mean of 8.5 years between the procedure and the contact. Among these, three (1.5\%) reported persistent memory disorders and $73 \%$ considered ECT a good treatment.

Conclusion: ECT has been performed according to international guidelines. In the vast majority of cases, undesirable effects were temporary and not severe. Response to ECT was positive in most cases, particularly in catatonic patients.

Keywords: Electroconvulsive therapy, treatment outcome, psychiatric somatic therapies, treatment, general hospital psychiatry.
\end{abstract}

\section{Resumo}

Objetivo: Descrever o perfil sociodemográfico e clínico de pacientes submetidos a eletroconvulsoterapia (ECT) em um hospital geral universitário.

Método: Neste estudo retrospectivo, foram revisados os prontuários de todos os pacientes submetidos a ECT entre janeiro de 1988 e janeiro de 2008 na unidade psiquiátrica do hospital geral da Universidade Estadual de Campinas (UNICAMP). Os pacientes/familiares foram contatados por telefone para a coleta de dados de seguimento.

Resultados: Um total de 200 prontuários foram revisados. A maioria dos pacientes era do sexo feminino, com uma idade média de 39 anos e história de hospitalização psiquiátrica prévia. As principais indicações para ECT foram depressão e catatonia. Complicações foram observadas em menos de metade dos casos, e a maioria delas teve caráter temporário e não grave. Houve resultado psiquiátrico favorável em $89,7 \%$ dos pacientes, especialmente os catatônicos $(100 \%, p=0,02)$. Trinta e nove por cento dos casos foram contatados por telefone, a uma média de 8,5 anos decorridos entre o procedimento e o contato. Entre estes, três $(1,5 \%)$ relataram transtornos amnésticos persistentes e $73 \%$ consideraram a ECT um bom tratamento.

Conclusão: A ECT foi realizada de acordo com diretrizes internacionais. Na grande maioria dos casos, efeitos indesejáveis foram temporários e não graves. A resposta à ECT foi positiva na maioria dos casos, especialmente em pacientes catatônicos. Descritores: Eletroconvulsoterapia, resultado de tratamento, tratamentos somáticos em psiquiatria, tratamento, unidade psiquiátrica em hospital geral.

\footnotetext{
${ }^{1}$ MD. Department of Medical Psychology and Psychiatry, School of Medical Sciences, Universidade Estadual de Campinas (UNICAMP), Campinas, SP, Brazil. ${ }^{2}$ MD, PhD. Department of Medical Psychology and Psychiatry, School of Medical Sciences, UNICAMP, Campinas, SP, Brazil.

Part of the results of this article were presented at 18th European Congress of Psychiatry, held in 2010 in Munich, Germany.

Financial support: Programa Institucional de Bolsas de Iniciação Científica (PIBIC).

Submitted Sep 11 2012, accepted for publication Apr 14 2013. No conflicts of interest declared concerning the publication of this article.

Suggested citation: Santos Jr A, Oliveira MC, Andrade TS, Freitas RR, Banzato CE, Azevedo RC, et al. Twenty years of electroconvulsive therapy in a psychiatric unit at a university general hospital. Trends Psychiatry Psychother. 2013;35(3):229-33.
} 


\section{Introduction}

The American Psychiatric Association has established guidelines for the use of electroconvulsive therapy (ECT)..$^{1-3}$ Even though some resistance is still observed, ECT is the first-choice treatment in the following cases: when a fast, consistent response is needed, when the risks of other treatment modalities are greater, or when there is previous history of poor response to drugs and/or good response to ECT. ${ }^{1-4}$ ECT is recognized as a biological therapy by the Brazilian Federal Medical Council $^{5}$ and is strongly recommended as a treatment for severe depression, both unipolar and bipolar, especially in the presence of psychotic symptoms, high risk of suicide, physical deterioration, or resistance/ refractoriness to antidepressants. It is also useful for rapid control of catatonic symptoms and severe manic states. ${ }^{1-3,6}$

Studies show no absolute contraindications to ECT. However, some situations of potential risk have been described, e.g., intracranial lesions or conditions associated with increased intracranial pressure, history of stroke, recent myocardial infarction with complications, severe arterial hypertension, presence of risk factors for intracranial hemorrhage, and conditions associated with a 4 or 5 risk score according to the American Society of Anesthesiologists (ASA) classification. ${ }^{3}$

Regarding adverse effects, the current technique is associated with low morbidity-mortality rates. Mortality ranges from 2-4.5 deaths per 100,000 procedures, which is comparable to the anesthetic risk of small surgeries. ${ }^{7}$ Major complications include confusion, delirium, transient headache, muscle pain, nausea, vomiting, prolonged seizures, teeth damages, and circulatory failure. Benign arrhythmias are frequent during application and in the immediate postictal period. ${ }^{3}$ The most important adverse effect of ECT is memory deficit, which may manifest as postictal confusion, anterograde and/or retrograde amnesia, or, in a minority of patients, long-term subjective memory deficit. ${ }^{8}$ Amnesiac episodes may persist from 1 to 6 months after the end of sessions; acquisition and retention of new memories are not impaired. ${ }^{9}$

Despite the relevance of ECT for patients with severe mental disorders, there are still few Brazilian studies investigating patients' profiles, appropriate indications, outcomes, and undesirable effects. ${ }^{10,11}$ This study aimed to describe data collected at a service with 20 years of experience in ECT, with a focus on the efficacy and safety of this treatment modality.

\section{Method}

The clinical charts of all patients undergoing ECT between January 1988 and January 2008 at the psychiatric unit of the general hospital of Universidade Estadual de Campinas (UNICAMP) were reviewed. The 14-bed psychiatric unit is part of a high-complexity hospital serving an area with approximately 5,000,000 inhabitants. ${ }^{12}$ It provides clinical care for inpatients with severe mental disorders and with a high rate of clinical comorbidities. In addition, it is the only service offering ECT in the region.

The following data were collected from patient records: sociodemographic information, clinical profile (diagnosis, previous psychiatric hospitalizations, family history of mental disorders, presence of clinical comorbidities), and ECT data, i.e., number of sessions, complications during and immediately after the procedure (within 72 hours), late complications (more than 72 hours after the procedure), and treatment response. Treatment outcome was categorized into four levels (excellent, good, indifferent, or poor), taking into account both the psychiatrists' reports of mental examinations conducted with each patient after the procedure and their mental status at the time of hospital discharge. To assure accuracy of treatment outcome information, the category assigned to each case was discussed among the investigators. Reports of excellent and good responses were later grouped together, as well as reports of indifferent and poor responses, in order to investigate differences in treatment response among the main diagnostic groups treated with ECT. The chi-square and Fisher's exact tests were used to compare the two groups, at a statistical significance of $p<0.05$. Followup telephone contacts were performed with patients and relatives.

Descriptive data analysis was performed using the Statistical Package for the Social Sciences (SPSS), version 11.5. The study was approved by the Ethics Committee of the School of Medical Sciences of UNICAMP (protocol no. 130074), with exemption of the need to obtain informed consent for the consultation of medical records. During follow-up telephone contacts, a consent statement was read to the patient and/or relative prior to the interview. All patients contacted by telephone agreed to undertake the interview.

\section{Results}

Over the 20-year period studied, 212 inpatients underwent ECT, but 12 charts (5.6\%) could not be found. Of the 200 patients, 20 underwent ECT in two different 
hospitalizations; five in three occasions; and one in four cycles, amounting to 26 repeaters. Mean age of the participants was 39.4 years (standard deviation $[\mathrm{SD}]=$ 17.3; median $=35)$, and $125(62.5 \%)$ were female.

Previous psychiatric hospitalizations were mentioned in $50 \%$ of the cases (mean $=2.6$; minimum $=1$; maximum $=13$ ), and $49 \%$ had a family history of mental

Table 1 - Demographic characteristics, psychiatric diagnoses, and electroconvulsive therapy-related adverse effects and complications

\begin{tabular}{|c|c|c|}
\hline & $\mathbf{n}$ & $\%$ \\
\hline \multicolumn{3}{|l|}{ Age (years) } \\
\hline $13-30$ & 72 & 36.0 \\
\hline $31-50$ & 72 & 36.0 \\
\hline$>50$ & 56 & 28.0 \\
\hline \multicolumn{3}{|l|}{ Education (years) } \\
\hline$<8$ & 109 & 66.9 \\
\hline$\geq 8$ & 54 & 31.1 \\
\hline \multicolumn{3}{|l|}{ Marital status } \\
\hline Single & 77 & 41.6 \\
\hline Married & 78 & 42.2 \\
\hline Divorced/widow & 30 & 16.2 \\
\hline \multicolumn{3}{|l|}{ Occupational status } \\
\hline Economically active & 41 & 29.5 \\
\hline Economically inactive & 98 & 70.5 \\
\hline \multicolumn{3}{|l|}{ Primary psychiatric diagnosis } \\
\hline Depression with psychotic features & 73 & 36.5 \\
\hline Depression without psychotic features & 62 & 31.0 \\
\hline Catatonic schizophrenia & 38 & 19.0 \\
\hline Mania & 37 & 18.5 \\
\hline \multicolumn{3}{|l|}{ Adverse effects during the procedure } \\
\hline None & 108 & 54.0 \\
\hline Arrhythmia & 42 & 21.0 \\
\hline Prolonged seizure & 23 & 11.5 \\
\hline Hypertension peak & 22 & 11.0 \\
\hline Anesthetic problems & 12 & 6.0 \\
\hline Vomit & 6 & 3.0 \\
\hline Tooth fracture & 4 & 2.0 \\
\hline \multicolumn{3}{|l|}{ Immediate complications* } \\
\hline None & 92 & 46.0 \\
\hline Mental confusion & 45 & 22.5 \\
\hline Headache & 30 & 15.0 \\
\hline Gastrointestinal disorders & 23 & 11.5 \\
\hline Lacunar amnesia & 20 & 10.0 \\
\hline Sleeping disorders & 15 & 7.5 \\
\hline Retrograde amnesia & 14 & 7.0 \\
\hline \multicolumn{3}{|l|}{ Late complications $^{+}$} \\
\hline None & 162 & 81.0 \\
\hline Lacunar amnesia & 10 & 5.0 \\
\hline Mental confusion & 9 & 4.5 \\
\hline Retrograde amnesia & 8 & 4.0 \\
\hline Headache & 7 & 3.5 \\
\hline
\end{tabular}

* Within 72 hours after the procedure.

+ More than 72 hours after the procedure. disorders. Comorbid physical conditions were found in $71.5 \%$ of the patients, especially arterial hypertension (49.5\%) and diabetes (25.5\%).

The mean number of sessions in each ECT cycle was $7.6(\mathrm{SD}=3.8 ;$ minimum $=1 ;$ maximum $=24$ sessions $)$. Application was unilateral in 80 participants $(46.2 \%)$, bilateral in $40(23.1 \%)$, and both unilateral and bilateral in $53(30.6 \%)$ ( $n=173$ with this information available).

Table 1 shows information about diagnoses and undesirable effects recorded for every patient's first or only hospitalization requiring ECT.

Patients who underwent ECT in two or more hospitalizations $(n=26)$ did not differ from those receiving only one ECT cycle in any sociodemographic, clinical, or ECT-related variable.

Response to ECT was considered excellent in 75 cases (38.9\%), good in 98 (50.8\%), indifferent in 15 (7.8\%), and poor in $5(2.6 \%)$. Among patients with a primary diagnosis of catatonic schizophrenia, response to ECT was reported as excellent $(54.1 \%)$ or good $(45.9 \%)$ in all cases. Taking together excellent/good responses vs. indifferent/poor ones, ECT showed a statistically superior response rate in this diagnostic group when compared to patients with other diagnoses (chi-square and Fisher's exact test, $\mathrm{p}=0.02$ ).

Telephone contact was successful in 68 cases (34\%). In eight cases, information was collected exclusively from relatives: in four cases, patients were hospitalized at the time of the phone call, and the other four patients had died (two from cancer, one suicide, and one of an unknown cause). Time elapsed between ECT and the telephone call varied from 1.1 to 20 years (mean $=8.5, \mathrm{SD}=5.5)$. Most patients $(84.1 \%)$ were still under psychiatric treatment, and $47.5 \%$ did not require psychiatric hospitalizations after ECT; $39 \%$ had 1-3 subsequent hospitalizations; and $13.6 \%$ had four or more.

Three patients $(1.5 \%)$ reported persistent ECT undesirable effects: two reported memory impairment within 6 months after the procedure (already remitted), and one complained of persistent memory impairment. Seventy three percent considered ECT a good treatment, $14.3 \%$ did not considered it good, and $12.7 \%$ did not express an opinion.

\section{Discussion}

This study describes data collected over 20 years of ECT in a psychiatric unit of a university general hospital, comprising one of the largest samples of cases in Brazil and contributing information to the national data bank on this procedure. 


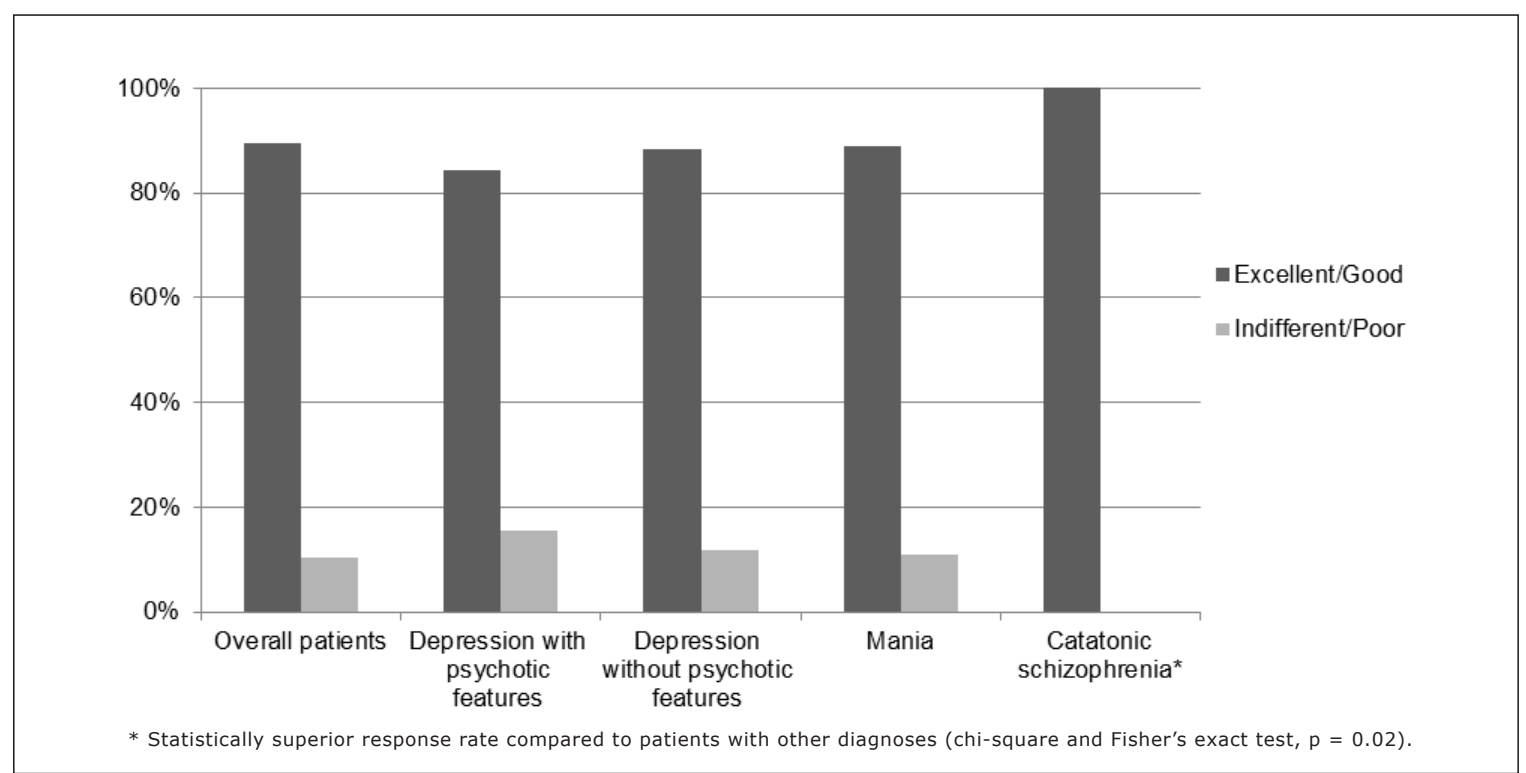

Figure 1 - Responses to electroconvulsive therapy

Patient profiles, mean number of sessions per patient and diagnoses for which the procedure was indicated are in concordance with international standards. ${ }^{3,11}$ Almost $20 \%$ of the patients who underwent ECT were catatonic, a first-line indication for ECT, where the fast relief of symptoms is essential to prevent lethality due to severe psychomotor retardation or refusal of food and drink. ${ }^{2,13}$

The complications reported by our patients were the same already documented in previous studies. Most of them were mild and reversible, and occurred mainly during or immediately after the procedure. Some may be related to the anesthesia, e.g., nauseas, prolonged seizures, and postictal confusion.7,9,14-16

The response to ECT was positive (good/excellent) in the vast majority of cases $(89.7 \%)$, reinforcing the importance of this therapeutic method in the treatment of severe mental disorders. This finding is in concordance with other recent studies ${ }^{9,17-19}$ that show that ECT, when well applied and accurately indicated, is effective and safe, and can lead to improvements in quality of life through the rapid mitigation of symptoms. Despite its great clinical value, ECT is still underestimated in Brazilian public health policies, because of prejudice and misconceptions spread by the media and lay press. ${ }^{1,10}$ Follow-up telephone calls reinforced the low prevalence of undesirable effects and the patients' long-lasting positive opinion about the procedure. ${ }^{17}$

A limitation of this study was its retrospective nature, based on information not collected using a standardized assessment form, but rather mostly from medical records. ${ }^{11}$ However, we could argue that the study was performed at a university service, which increases the reliability of data due to the constant discussion and supervision of all cases by experienced professors. Moreover, cases causing doubts about the type of response to treatment were carefully discussed among the investigators. Another limitation was that telephone contact was successful in only one-third of the cases. This bias happened because of the long time elapsed between ECT and the phone call (mean of 8.5 years) and also due to changes in telephone numbers and addresses (which is very common in Brazil). These factors may have contributed to the limited body of follow-up data collected.

ECT has been performed in UNICAMP according to international guidelines regulating the application and monitoring of clinical response and adverse side effects. ${ }^{20}$ Satisfactory clinical results were observed in the majority of cases, both at the time of the procedure and during the follow-up. Undesirable effects, in most cases, were temporary and not severe.

Despite mental health policies that may reprobate or even prevent its use, it is necessary to recognize that, when well indicated and carefully performed, ECT is a very effective treatment option and should be made available for selected patients. Our results reinforce the important role played by this therapy in the treatment of severe and often life-threatening mental disorders. 


\section{References}

1. Perizzolo J, Berlim MT, Szobot CM, Lima AF, Schestatsky S, Fleck MP. Aspectos da prática da eletroconvulsoterapia: uma revisão sistemática. Rev Psiquiatr Rio Gd Sul. 2003;25:327-34.

2. Pandya M, Pozuelo L, Malone D. Electroconvulsive therapy: what the internist needs to know. Cleve Clin J Med. 2007;74:679-85.

3. American Psychiatric Association (APA). The practice of ECT: recommendations for treatment, training, and privileging. $A$ task force report of the American Psychiatric Association. 2nd ed. Washington: American Psychiatric Association; 2001.

4. Pastore DL, Bruno LM, Nardi AE, Dias AG. O uso da eletroconvulsoterapia no Instituto de Psiquiatria da Universidade Federal do Rio de Janeiro no período de 2005 a 2007. Rev Psiquiatr Rio Gd Sul. 2008;30:175-81.

5. Conselho Federal de Medicina, Brasília. Resolução CFM no. 1.640/2002, jul 2002. http://www.portalmedico.org.br/ resolucoes/cfm/2002/1640_2002.htm. Accessed 2012 Sep 12.

6. Dierckx B, Heijnen WT, van den Broek WW, Birkenhäger TK. Efficacy of electroconvulsive therapy in bipolar versus unipolar major depression: a meta-analysis. Bipolar Disord. 2012;14:146-50.

7. Mayo C, Kaye AD, Conrad E, Baluch A, Frost E. Update on anesthesia considerations for electroconvulsive therapy. Middle East J Anesthesiol. 2010;20:493-8.

8. Verwijk E, Comijs HC, Kok RM, Spaans HP, Stek ML, Scherder EJ. Neurocognitive effects after brief pulse and ultrabrief pulse unilateral electroconvulsive therapy for major depression: a review. J Affect Disord. 2012;140:233-43.

9. Moser CM, Lobato MI, Belmonte-de-Abreu P. Evidence of the effectiveness of electroconvulsive therapy in the psychiatric practice. Rev Psiquiatr Rio Gd Sul. 2005;27:302-10.

10. Ribeiro RB, Melzer-Ribeiro DL, Rigonatti SP, Cordeiro Q. Electroconvulsive therapy in Brazil after the "psychiatric reform": a public health problem--example from a university service. J ECT. 2012;28:170-3.
11. Azi LA, Dalgalarrondo P, Botega NJ. Electroconvulsive therapy: a retrospective study of 50 cases. J Bras Psiquiatr. 1999;48:493-98.

12. Dalgalarrondo $P$, Botega NJ, Banzato CE. Pacientes que se beneficiam de internação psiquiátrica em hospital geral. Rev Saude Publica. 2003;37:10-20.

13. Petrides G, Tobias KG, Kellner CH, Rudorfer MV. Continuation and maintenance electroconvulsive therapy for mood disorders: review of the literature. Neuropsychobiology. 2011;64:129-40.

14. Baghai TC. Möller HJ. Electroconvulsive therapy and its different indications. Dialogues Clin Neurosci. 2008;10:105-17.

15. Pagnin D, de Queiroz V, Pini S, Cassano GB. Efficacy of ECT in depression: a meta-analytic review. J ECT. 2004;20:13-20.

16. Mathys M, Mitchell BG. Targeting treatment-resistant depression. J Pharm Pract. 2011;24:520-33.

17. Antunes PA, Rosa MA, Abreu PSB, Lobato MIR, Fleck MP. Electroconvulsive therapy in major depression: current aspects. Rev Bras Psiquiatr. 2009;31:S26-33.

18. Braga RJ, Petrides G. Terapias somáticas para transtornos psiquiátricos resistentes ao tratamento. Rev Bras Psiquiatr. 2007;29:S77-84.

19. Bharadwaj V, Grover S, Chakrabarti S, Avasthi A, Kate N. Clinical profile and outcome of bipolar disorder patients receiving electroconvulsive therapy: a study from north India. Indian J Psychiatry. 2012;54:41-7.

20. Scott AI. Electroconvulsive therapy, practice and evidence. $\mathrm{Br}$ J Psychiatry. 2010;196:171-2.

\section{Correspondence}

Amilton dos Santos Júnior

Departamento de Psicologia Médica e Psiquiatria - FCM-Unicamp

Cidade Universitária Zeferino Vaz, Distrito de Barão Geraldo

13083-970 - Campinas, SP - Brazil

Tel.: +55 (19) 3521.7514

E-mail: amilton@fcm.unicamp.br 